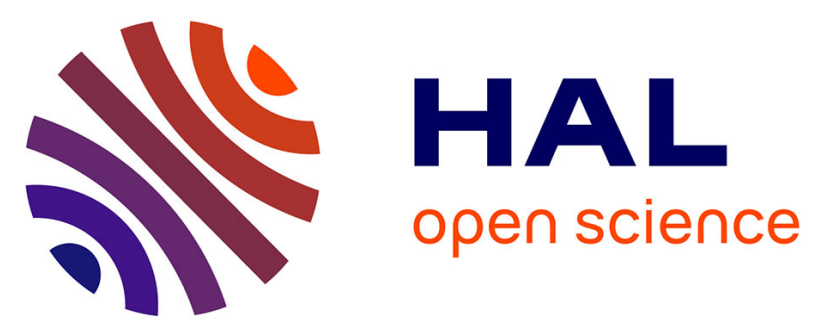

\title{
HoSAGE: Sarcopenia in Older Patients before and after Treatment with Androgen Deprivation Therapy and Radiotherapy for Prostate Cancer
}

\author{
Anne-Laure Couderc, X. Muracciole, E. Nouguerede, D. Rey, S. Schneider, P. \\ Champsaur, E. Lechevallier, Loïc Lalys, P. Villani
}

\section{To cite this version:}

Anne-Laure Couderc, X. Muracciole, E. Nouguerede, D. Rey, S. Schneider, et al.. HoSAGE: Sarcopenia in Older Patients before and after Treatment with Androgen Deprivation Therapy and Radiotherapy for Prostate Cancer. Journal of Nutrition, Health \& Aging, 2020, 24 (2), pp.205-209. 10.1007/s12603019-1294-7 . hal-03030962

\section{HAL Id: hal-03030962 https://hal.science/hal-03030962}

Submitted on 2 Dec 2020

HAL is a multi-disciplinary open access archive for the deposit and dissemination of scientific research documents, whether they are published or not. The documents may come from teaching and research institutions in France or abroad, or from public or private research centers.
L'archive ouverte pluridisciplinaire HAL, est destinée au dépôt et à la diffusion de documents scientifiques de niveau recherche, publiés ou non, émanant des établissements d'enseignement et de recherche français ou étrangers, des laboratoires publics ou privés. 


\title{
HoSAGE: Sarcopenia in Older Patients before and after Treatment with Androgen Deprivation Therapy and Radiotherapy for Prostate Cancer
}

\author{
Anne-Laure Couderc, X. Muracciole, E. Nouguerede, D. Rey, S. Schneider, P. \\ Champsaur, E. Lechevallier, Loïc Lalys, P. Villani
}

\section{To cite this version:}

Anne-Laure Couderc, X. Muracciole, E. Nouguerede, D. Rey, S. Schneider, et al.. HoSAGE: Sarcopenia in Older Patients before and after Treatment with Androgen Deprivation Therapy and Radiotherapy for Prostate Cancer. Journal of Nutrition, Health and Aging, Springer Verlag (Germany), 2020, 24 (2), pp.205-209. 10.1007/s12603-019-1294-7 . hal-03030962

\section{HAL Id: hal-03030962 \\ https://hal.archives-ouvertes.fr/hal-03030962}

Submitted on 2 Dec 2020

HAL is a multi-disciplinary open access archive for the deposit and dissemination of scientific research documents, whether they are published or not. The documents may come from teaching and research institutions in France or abroad, or from public or private research centers.
L'archive ouverte pluridisciplinaire HAL, est destinée au dépôt et à la diffusion de documents scientifiques de niveau recherche, publiés ou non, émanant des établissements d'enseignement et de recherche français ou étrangers, des laboratoires publics ou privés. 


\title{
HOSAGE: SARCOPENIA IN OLDER PATIENTS BEFORE AND AFTER TREATMENT WITH ANDROGEN DEPRIVATION THERAPY AND RADIOTHERAPY FOR PROSTATE CANCER
}

\author{
A.L. COUDERC ${ }^{1,2}$, X. MURACCIOLE ${ }^{3}$, E. NOUGUEREDE ${ }^{1}$, D. REY $^{1}$, S. SCHNEIDER ${ }^{4,5}$, \\ P. CHAMPSAUR ${ }^{6,8}$, E. LECHEVALLIER ${ }^{7,8}$, L. LALYS $^{2}$, P. VILLANI ${ }^{1,2}$
}

\begin{abstract}
1. Internal Medicine, Geriatry and Therapeutic Unit, AP-HM, Marseille, France and Coordination Unit for Geriatric Oncology (UCOG), PACA West, France; 2. Aix-Marseille Université, CNRS, EFS, ADES, Marseille, France; 3. Radiotherapy Unit, AP-HM, Marseille, France; 4. Department of Clinical Nutrition, Nice CHU, Archet Hopsital, Nice, France; 5. Nice SophiaAntipolis University, Nice, France; 6. Radiology Unit, Sainte Marguerite Hospital, AP-HM, Marseille, France; 7. Urological Surgery Unit, Conception Hospital, AP-HM, Marseille, France; 8. Aix-Marseille University, Marseille, France. Corresponding author: Anne-Laure Couderc, Assistance Publique Hopitaux de Marseille, Marseille, France, anne-laure.couderc@ap-hm.fr
\end{abstract}

\begin{abstract}
Background: Sarcopenia is a muscle disease defined by a loss of muscle strength associated to a decrease in skeletal muscle mass. In addition to aging, many factors may contribute to sarcopenia as cancer and/or androgen deprivation therapy (ADT). Objectives: The aims of this study are to describe the prevalence of sarcopenia in older prostate cancer patients before initiation of treatment with ADT and radiotherapy, and to evaluate the impact of ADT on the occurrence or aggravation of sarcopenia in this population. Design: longitudinal study. Participants and setting: Sarcopenia was prospectively evaluated in 31 consecutive patients aged 70 to 88 years, referred in one hospital unit of south eastern France, for a comprehensive geriatric assessment (CGA) before cancer treatment initiation. Measurements and results: CGA, measures of muscle strength and physical performances were performed at baseline (T0) and at the end of cancer treatment (T1). Appendicular skeletal muscle mass was measured by Dual-energy X-ray absorptiometry (DXA) at the end of treatment. At T0, 8 patients (among 31) had a probable sarcopenia according to European consensus, and 18 had altered physical performance. At T1, 15 patients (among 19) had abnormal one leg balance test. Finally, only one patient had a sarcopenia confirmed by DXA. Conclusion: This preliminary study showed a high prevalence of muscle disorders before initiation of ADT in a population of elderly cancer prostate patients with intermediate frailty status, and an increased risk of falls at the end of ADT. This highlighted the importance of screening for sarcopenia before treatment initiation, to prevent the occurrence or aggravation of sarcopenia by possible adjustment of treatment, and implementation of appropriate exercise and nutrition interventions.
\end{abstract}

Key words: Sarcopenia, older patients, prostate cancer, androgen deprivation therapy, radiotherapy.

\section{Introduction}

Prostate cancer is the most common cancer in old men (1). Six months to three years androgen deprivation therapy (ADT) is the reference treatment in localized, intermediate, and high-risk prostate cancer, associated with radiotherapy (2). ADT use has numerous side effects including alteration of physical functions and decrease of quality of life (3). Moreover, androgen inhibitors have been associated with metabolic effects that could lead to or worsen obesity, cardiovascular disease, sarcopenia or osteoporosis (4)

Sarcopenia is a muscle disorder characterized by loss of muscle strength and muscle mass with or without an increase of fat mass (5). In addition to aging, many factors may contribute to sarcopenia, as malnutrition, inactivity, or cancer disease. It is a risk factor of early death, falls and mobility impairment in older populations (5). Diagnosis is based on a combination of measures of muscle mass and muscle strength that vary according to the guidelines (table 1). Measures of physical performance are used to appreciate the severity of the disease.

New updated recommendations of the revised European guidelines (EWGSOP2) (5) aim to increase awareness of Received September 1, 2019 sarcopenia, promoting detection, prevention and treatment. In France, prevalence of sarcopenia in the elderly is poorly known and, until now, its detection in patients with ADT, is not part of national guidelines on prostate cancer management. In this particular context, our study aims to document (1) the prevalence of muscle disorders in older prostate cancer patients before initiation of ADT and radiotherapy, and (2) the occurrence and/or aggravation of muscle disorders and sarcopenia at the end of treatment.

\section{Methods}

This feasibility study was led between October 2018 and April 2019, in the Internal Medicine, Geriatric and Therapeutics Unit of the Marseille's University Hospital (AP-HM). During this period, all consecutive patients, aged 70 years or more, referred for a comprehensive geriatric assessment before initiation of radiotherapy and ADT for a localized or locally advanced prostate cancer, were enrolled in the study.

\section{Data collection}

Muscle mass was estimated at the end of cancer treatment with the Appendicular Skeletal Muscle Mass (ASMM) 


\section{HOSAGE}

Table 1

Main diagnosis criteria of sarcopenia for men

\begin{tabular}{|c|c|c|c|}
\hline Consensus & Measures & Cut-off points & Sarcopenia diagnosis \\
\hline $\begin{array}{l}\text { International working group on } \\
\text { sarcopenia (6) }\end{array}$ & $\begin{array}{l}\text { Physical function } \\
\text { Skeletal muscle mass }\end{array}$ & $\begin{array}{l}\text { Gait speed }<1 \mathrm{~m} / \mathrm{s}(\text { over } 4 \mathrm{~m}) \\
\text { DXA : ASSM } / \text { height } 2 \leq 7,23 \mathrm{~kg} / \mathrm{m}^{2}\end{array}$ & $\begin{array}{l}\text { Measure of physical function (Gait } \\
\text { speed) and measure of lean mass } \\
\text { (DXA) }\end{array}$ \\
\hline $\begin{array}{l}\text { European working group on sarcopenia } \\
\text { in older people (EWGSOP2) (5) }\end{array}$ & $\begin{array}{l}\text { Grip strength /chair stand test } \\
\text { Skeletal muscle mass } \\
\text { Performances }\end{array}$ & $\begin{array}{l}\text { Grip strength }<27 \mathrm{~kg} \\
\text { Chair stand test }>15 \mathrm{~s} \text { for } 5 \text { rises } \\
\text { DXA: ASSM } / \text { height }{ }^{2}<7.0 \mathrm{~kg} / \mathrm{m}^{2} \\
\text { Gait speed } \leq 0.8 \mathrm{~m} / \mathrm{s} \\
\text { SPPB Score } \leq 8 \text { points } \\
\text { TUG } \geq 20 \mathrm{~s} \\
400 \text {-meter walk completed in } \geq 6 \mathrm{~min} \text { or } \\
\text { not completed }\end{array}$ & $\begin{array}{l}\text { Reduced muscle strength : probable } \\
\text { sarcopenia } \\
\text { Reduced muscle mass : confirmed } \\
\text { sarcopenia } \\
\text { Reduced performances: severe } \\
\text { sarcopenia }\end{array}$ \\
\hline Asian Working Group for Sarcopenia [7] & $\begin{array}{l}\text { Strength Performance } \\
\text { Skeletal muscle mass }\end{array}$ & $\begin{array}{l}\text { Grip strength }<26 \mathrm{~kg} \\
\text { Gait speed }<0.8 \mathrm{~m} / \mathrm{s}(\text { over } 6 \mathrm{~m}) \\
\text { DXA : ASSM } / \mathrm{height}^{2}<7,0 \mathrm{~kg} / \mathrm{m}^{2} \\
\text { BIA }<7.0 \mathrm{~kg} / \mathrm{m}^{2}\end{array}$ & $\begin{array}{l}\text { Low lean mass (DXA) and reduced } \\
\text { muscle function (Grip strength and } \\
\text { Gait speed) }\end{array}$ \\
\hline
\end{tabular}

SPPB : Short Physical Performance Battery; TUG : Timed Up and Go; ASSM: Appendicular Skeletal Muscle Mass; BIA: Bioelectrical Impedance Analysis; DXA: Dual-energy X-ray absorptiometry; The skeletal muscle mass can also be estimated by bioelectrical impedance analysis (BIA), magnetic resonance imaging (MRI) or computed tomography (CT) in research studies.

measured with dual-energy X-ray absorptiometry (DXA). Results were adjusted for body size using height squared $\left(\mathrm{ASMM} /\right.$ height $^{2}$ ) and chosen cut-off point for low muscle quantity was $<7.0 \mathrm{~kg} / \mathrm{m}^{2}(5)$.

All other information was collected twice, before initiation and at the end of cancer treatment. Muscle strength was measured using hand grip strength test (GS) that was conducted using the methodology of the American Society of Hand Therapists (ASHT) (8) and the cut-off points recommended in the EWGSOP2 (5). To determine severity of sarcopenia, physical performances were measured with gait speed (9), and "Timed up and go test" (10) (TUG). Geriatric frailties were detected using G8 screening tool (11), vulnerability score (ECOG-PS (12)), Activities of Daily Living (ADL) and Instrumental Activities of Daily Living (IADL) tools $(13,14)$. Fall risk was assessed using One Leg Balance test (OLBT) (15) and history of falls. Nutritional status was evaluated using Body Mass Index (BMI), Albumin level, Mini Nutritional Assessment scale (MNA) (16) and protein intake. Definition of malnutrition was issued of French Health Ministry recommendations (BMI $<21$ and/or Albumin level $<35 \mathrm{~g} / 1$ and/or MNA<17) (17). The Mini Mental State Examination (MMSE) (18) and the Clock Drawing (CD) test were used to detect cognitive disorders $(\mathrm{MMSE}<24$ and/or CD test $<6$ ). Patients were asked about their socio-demographic characteristics and their life habits (physical activity, alcohol and tobacco consumptions). People living alone and/or with no family caregiver within 50 kilometers were considered as socially isolated. Finally, cancer clinical characteristics and treatment, poly-medication ( $\geq 5$ drugs), and comorbidities were issued of medical records. All data were collected by the same physician. This study was approved by the Ethics Committee.

\section{Statistical analysis}

Chi square test and t-test were used to perform comparative analysis of discrete and continuous variable respectively. McNemar and Wilcoxon tests were respectively used to analyze paired discrete and continuous data. All analyses were done using SPSS for Windows, version 17.0.

\section{Results}

\section{Prevalence of sarcopenia and muscle disorders before treatment initiation}

Baseline characteristics of the 31 patients enrolled are detailed in table 2 . Mean age was 80.4 years, most were highly educated $(n=19)$ and a majority had an income greater than two times the minimum old-age pension $(n=16)$. Half $(n=14)$ had a high-risk prostate cancer, eight were dependent for IADL, and only eleven reported regular physical activity. According to the revised European consensus, eight patients $(25 \%)$ had a probable sarcopenia at baseline. Moreover 18 patients had altered physical performance with $\mathrm{TUG} \geq 20$ s for eight of them, OLBT $<5 \mathrm{~s}$ for thirteen and gait speed $\leq 0.8 \mathrm{~m} / \mathrm{s}$ for eleven. Compared with patients without sarcopenia, those with probable sarcopenia had more geriatric frailties, higher fall risk, more medications, and more often high-risk cancer, although the differences did not reach significance (table 2).

\section{Prevalence of sarcopenia and muscle disorders at the end of treatment}

Nineteen patients received ADT and radiotherapy, and had a follow-up visit at the end of treatment. Radiotherapy delivered was on average $75.6 \mathrm{~Gy}$. Eight patients received ADT for 6 months, ten for 15 months, and the last one for 18 months. Among the thirteen patients with no sarcopenia at baseline, six 
Table 2

Sociodemographic, oncologic and geriatric characteristics according to sarcopenia status before initiation of oncologic treatment $(\mathrm{n}=31$ old men with prostate cancer)

\begin{tabular}{|c|c|c|c|c|c|c|c|}
\hline \multirow[t]{2}{*}{ Characteristics } & \multicolumn{2}{|c|}{ Total population } & \multicolumn{2}{|c|}{ No sarcopenia (hand grip $\geq 27 \mathrm{~kg}$ ) $N=23$} & \multicolumn{3}{|c|}{ Probable sarcopenia (hand grip $<27 \mathrm{~kg}$ ) N=8 } \\
\hline & $\begin{array}{c}\text { N or } \\
\text { Mean } \pm \text { ET }\end{array}$ & $\begin{array}{c}(\%) \text { or } \\
{[\min -\max ]}\end{array}$ & $\begin{array}{c}\text { Nor } \\
\text { Mean } \pm \text { ET }\end{array}$ & $\begin{array}{c}(\%) \text { or } \\
{[\min -\max ]}\end{array}$ & $\begin{array}{c}\text { N or } \\
\text { Mean } \pm \text { ET }\end{array}$ & $\begin{array}{c}(\%) \text { or } \\
{[\min -\mathbf{m a x}]}\end{array}$ & $\mathbf{p}$ \\
\hline \multicolumn{8}{|l|}{ Socio-demographic characteristics } \\
\hline Age & $80.5 \pm 4.3$ & [70-88] & $80.4 \pm 4.1$ & [73-88] & $80.6 \pm 4.9$ & [70-86] & 0.555 \\
\hline High school graduation or more & 20 & 66.4 & 13 & $(56.5)$ & 6 & $(75.0)$ & 0.215 \\
\hline Living $<50 \mathrm{~km}$ from treatment center & 26 & 83.9 & 18 & (78.3) & 8 & $(100.0)$ & 0.291 \\
\hline Caregiver present & 27 & 87.1 & 20 & $(86.9)$ & 7 & (87.5) & 1.000 \\
\hline Income $(\geq 2000)$ & 16 & 51.6 & 11 & $(47.8)$ & 5 & $(62.5)$ & 0.399 \\
\hline Social isolation * & 4 & 12.9 & 3 & $(13.0)$ & 1 & (12.5) & 1.000 \\
\hline \multicolumn{8}{|l|}{ Oncologic characteristics } \\
\hline Intermediate-risk prostate cancer & 14 & 45.2 & 13 & (56.5) & 1 & (12.5) & 0.077 \\
\hline High-risk prostate cancer & 14 & 45.2 & 8 & $(34.8)$ & 6 & $(75.0)$ & \\
\hline Unknown & 3 & 9.6 & 2 & (8.7) & 1 & $(12.5)$ & \\
\hline \multicolumn{8}{|l|}{ Geriatric characteristics } \\
\hline G8 score $(\leq 14)$ & 16 & 51.6 & 11 & $(47.8)$ & 5 & $(62.5)$ & 0.399 \\
\hline Dependence $\mathrm{ADL}<6$ & 1 & 3.3 & 0 & $(0.0)$ & 1 & (12.5) & NA \\
\hline IADL $<4$ & 8 & 77.4 & 5 & (21.7) & 3 & $(37.5)$ & 0.393 \\
\hline Nutrition BMI & $26.6 \pm 3.6$ & [21-42] & $27.0 \pm 4.0$ & {$[22-42]$} & $25.6 \pm 2.3$ & {$[21-28]$} & 0.682 \\
\hline Albumin & $41.8 \pm 2.5$ & {$[37.6-47.9]$} & $41.8 \pm 2.3$ & {$[37.6-47.0]$} & $41.8 \pm 3.1$ & {$[38.0-47.9]$} & 0.954 \\
\hline Protein intake** $(g)$ & $80.4 \pm 20.6$ & [21-110] & $85.5 \pm 14.2$ & [52-110] & $70.2 \pm 27.9$ & [21-108] & 0.186 \\
\hline Malnutrition $* * *$ & 3 & 9.6 & 2 & (8.7) & 1 & (12.5) & 1.000 \\
\hline Cognitive troubles & 4 & 12.9 & 2 & (8.7) & 2 & $(25.0)$ & 0.268 \\
\hline Depressive syndrome & 5 & 16.1 & 2 & $(8.7)$ & 3 & $(37.5)$ & 0.093 \\
\hline \multirow{2}{*}{$\begin{array}{ll}\text { Mobility } & \text { TUG }(\geq 20 \mathrm{~s}) \\
& \text { Gait speed }(\leq 0.8 \mathrm{~m} / \mathrm{s})\end{array}$} & 8 & 25.8 & 6 & $(26.0)$ & 2 & $(25.0)$ & 1.000 \\
\hline & 10 & 32.3 & 7 & $(30.4)$ & 3 & $(37.5)$ & 0.697 \\
\hline Fall risk $\quad$ One leg balance test $(<5 \mathrm{~s})$ & 13 & 41.9 & 9 & $(39.1)$ & 4 & $(50.0)$ & 0.689 \\
\hline Fall history (past 3 months) & 4 & 12.9 & 3 & $(13.0)$ & 1 & (12.5) & 1.000 \\
\hline Number of comorbidities & $3.4 \pm 1.6$ & {$[0-7]$} & $3.2 \pm 1.6$ & {$[0-7]$} & $3.9 \pm 1.6$ & {$[2-6]$} & 0.411 \\
\hline Polypharmacy ( $\geq 5$ drugs) & 18 & 58.1 & 12 & $(52.2)$ & 6 & $(75.0)$ & 0.412 \\
\hline Alcohol consumption $* * * *$ & 20 & 64.5 & 17 & (56.7) & 3 & $(10.0)$. & 0.181 \\
\hline Smoker or former smoker & 15 & 48.4 & 14 & $(46.7)$ & 1 & (3.3) & 0.080 \\
\hline \multicolumn{8}{|l|}{ Physical activity } \\
\hline Less than $30 \mathrm{~min}$ a week & 10 & 32.3 & 8 & $(34.8)$ & 2 & $(25.0)$ & 0.589 \\
\hline 30 min once or twice a week & 10 & 32.3 & 6 & (26.1) & 4 & $(50.0)$ & \\
\hline 30 min 3 times or more per week & 11 & 35.5 & 9 & (39.1) & 2 & $(25.0)$ & \\
\hline
\end{tabular}

* Social isolation : patient living alone with caregiver living over 50km away or without caregiver; ** Mean protein intake over 3 days in grams; *** Definition of the French High Health Authority (HAS): BMI <21 and/or Albumin <35g/L and/or MNA <17; **** At least one glass of wine by day

had a muscle strength decrease. No relation was found between muscle strength decrease and ADT duration. After ending treatment, fifteen patients had abnormal OLBT, suggesting a significant increase of fall risk.

Out of the 19 patients with a follow-up, six agreed to have their muscle mass measured with DXA. ASSM/height2 was lower than $7.0 \mathrm{~kg} / \mathrm{m}^{2}$ for two patients but only one had a sarcopenia according to the EWGSOP2 guidelines.

\section{Discussion}

In this study among 31 older patients with prostate cancer, the estimated prevalence of probable sarcopenia before cancer treatment was $25 \%$ according to the last European consensus. The first follow-up showed an increased risk of falling at the end of treatment.

Prevalence rate of sarcopenia varies between studies 
HOSAGE

Table 3

Comparison of sarcopenia status, social and geriatric characteristics before and after prostate cancer treatment $(\mathrm{N}=19)$

\begin{tabular}{|c|c|c|c|c|c|}
\hline \multirow[t]{2}{*}{ Characteristics } & \multicolumn{2}{|c|}{ T0 } & \multicolumn{2}{|c|}{ T1 } & \multirow[t]{2}{*}{$\mathbf{p}$} \\
\hline & $\mathrm{N}$ or Mean $\pm \mathrm{ET}$ & $(\%)$ or $[\min -\max ]$ & N or Mean \pm ET & $(\%)$ or $[\min -\max ]$ & \\
\hline Handgrip Strength & $30.6 \pm 8.7$ & [16-51] & $30.6 \pm 7.9$ & {$[20-50]$} & 0.875 \\
\hline Normal & 13 & $(68.4)$ & 13 & $(68.4)$ & 1.000 \\
\hline Probable sarcopenia $(<27 \mathrm{~kg})$ & 6 & (31.6) & 6 & & \\
\hline \multicolumn{6}{|l|}{ Social isolation } \\
\hline No & 15 & (78.9) & 17 & (89.5) & 0.500 \\
\hline Yes & 4 & $(21.1)$ & 2 & $(10.5)$ & \\
\hline \multicolumn{6}{|l|}{ Polymedication } \\
\hline$<5$ drugs & 8 & $(42.1)$ & 7 & $(36.8)$ & 1.000 \\
\hline$\geq 5$ drugs & 11 & $(57.9)$ & 12 & $(63.2)$ & \\
\hline \multicolumn{6}{|l|}{ Cognitive status } \\
\hline Normal & 19 & $(100)$ & 15 & (78.9) & $\mathrm{NA}^{\circ}$ \\
\hline Cognitive troubles & - & - & 4 & $(21.1)$ & \\
\hline \multicolumn{6}{|l|}{ Nutritional status } \\
\hline BMI & $26.1 \pm 2.6$ & [21-32] & $25.5 \pm 3.2$ & [18-31.9] & 0.177 \\
\hline Albumin & $41.7 \pm 2.6$ & [37.6-47.9] & $41.6 \pm 2.9$ & {$[37.3-48.4]$} & 0.798 \\
\hline Protein intake* & $75.7 \pm 22.5$ & {$[21-110]$} & $79.6 \pm 21.5$ & [36-114] & 0.445 \\
\hline Normal nutritional status & 17 & (89.5) & 17 & (89.5) & 1.000 \\
\hline Malnutrition** & 2 & $(10.5)$ & 2 & $(10.5)$ & \\
\hline \multicolumn{6}{|l|}{ Activities of Daily Living score } \\
\hline 6 & 18 & $(100)$ & 17 & (94.4) & $\mathrm{NA}^{\circ}$ \\
\hline$<6$ (Dependent) & - & - & 1 & $(5.6)$ & \\
\hline \multicolumn{6}{|c|}{ Instrumental Activities of Daily Living score } \\
\hline 4 & 16 & $(88.9)$ & 11 & $(61.1)$ & 0.125 \\
\hline$<4$ (Dependent) & 2 & $(11.1)$ & 7 & $(38.9)$ & \\
\hline \multicolumn{6}{|l|}{ Mobility } \\
\hline \multicolumn{6}{|l|}{ Physical activity } \\
\hline Less than 30 min a week & 8 & $(42.1)$ & 8 & $(42.1)$ & 1.000 \\
\hline More than 30 min a week & 11 & $(57.9)$ & 11 & $(57.9)$ & \\
\hline \multicolumn{6}{|l|}{ Timed up and go Test (TUG) } \\
\hline$<20$ s & 15 & (78.9) & 9 & (47.4) & 0.070 \\
\hline$\geq 20 \mathrm{~s}$ & 4 & $(21.1)$ & 10 & (52.6) & \\
\hline \multicolumn{6}{|l|}{ One leg balance test (OLBT) } \\
\hline$\geq 5 \mathrm{~s}$ & 10 & (52.6) & 4 & (21.1) & 0.031 \\
\hline$<5 \mathrm{~s}$ & 9 & (47.4) & 15 & (78.9) & \\
\hline \multicolumn{6}{|l|}{ Gait speed } \\
\hline$>0,8 \mathrm{~m} / \mathrm{s}$ & 12 & (66.7) & 12 & (66.7) & 1.000 \\
\hline$\leq 0.8 \mathrm{~m} / \mathrm{s}$ & 6 & (33.3) & 6 & (33.3) & \\
\hline
\end{tabular}

* Mean protein intake over 3 day in grams; ** Definition of the French High Health Authority (HAS): BMI <21 and/or Albumin $<35 \mathrm{~g} / \mathrm{L}$ and/or MNA $<17 ;{ }^{\circ}$ McNemar test application criteria were not met; $\mathrm{T} 0$ : before cancer treatment; $\mathrm{T} 1$ : at the end of cancer treatment

according to the population studied and the criteria used for diagnosis. Estimation of probable sarcopenia prevalence varies across studies from $1.6 \%$ in healthy elderly (19) to $40 \%$ in community-dwelling Brazilian old men (20). Using the EWGSOP definition, prevalence of confirmed sarcopenia in community-dwelling populations, varies from 1 to $29 \%$ (21). Risk factors as age, cancer, malnutrition, or frailty have been involved in the development of sarcopenia (22, 
23). Different studies have also shown a relation between sarcopenia and institutionalization of individuals (19) or low socio-economic status (20). Our study population consisted of community-dwelling older adults, highly educated and welloff, with good nutritional status, intermediate frailty status according to Fried criteria (24), and localized prostatic cancers with a favorable prognosis (1). Considering their health and social characteristics, they had a lower risk of sarcopenia than the populations usually described in the literature, especially those with cancer (22). The observed prevalence of probable sarcopenia was therefore higher than expected.

At the end of treatment, $80 \%$ of our studied population had an abnormal OLBT, suggesting a fall risk increase. This is consistent with results of others who reported incidence rates of falls in prostate cancer patients treated with ADT, up to twice as high than in those without ADT $(25,26)$. Among ADT side effects, several studies reported lean mass loss, and muscle strength decrease $(27,28)$, both related to ADT duration. Unlike others, we did not show any muscle loss or decrease in muscle strength in patients treated with ADT, probably because of the size of our study sample (19 follow-up until now and 6 patients who agreed to have their muscle mass measured). The small number of patients, and the lack of post treatment evaluation for part of them (ongoing treatment) are the major limitations of this preliminary study. However, thanks to first results, a hundred more patients will be enrolled (with a control group of prostate cancer patients receiving only radiotherapy) and followed for one year after the end of treatment.

Our study showed a high prevalence of muscle disorders among elderly considered at low risk of sarcopenia. This result stresses the importance of systematically screening for sarcopenia before initiating ADT, to reduce ADT adverse effects with adapted nutritional and exercise interventions (4, 29). Current guidelines for older adults with prostate cancer recommend to associate radiotherapy with 6 to 36 months of ADT. The close link between sarcopenia and frailty, and their negative impact on survival are well known. More studies are needed to improve knowledge about the risks of occurrence or aggravation of a sarcopenia during ADT, to help physicians to determine the modalities of treatment (as intermittent ADT (4) or shorter treatment (30)) offering patients the most satisfactory benefit-risk ratio.

\section{References}

1. Rebillard X, Grosclaude P, Leone N, et al. [Incidence and mortality of urological cancers in 2012 in France]. Progres En Urol J Assoc Francaise Urol Soc Francaise Urol 2013;23 Suppl 2:S57-65.

2. Mottet N, van den Bergh RCN, Briers E et al, 2018. EAU - ESUR - ESTRO - SIOG Guidelines on prostate cancer 2018 - European association of urology 2018. https:// uroweb.org/wp-content/uploads/EAU-ESUR-ESTRO-SIOG-Guidelines-on-ProstateCancer-large-text-V2.pdf Accessed August 2019

3. hmadi H and Daneshmand S. Androgen deprivation therapy for prostate cancer : long- term safety and patient outcomes. Patient Related Outcome Measures 2014;5:63-70

4. Mitsuzuka K, Arai Y. Metabolic changes in patients with prostate cancer during androgen deprivation therapy. International Journal of Urology 2018;25:45-53

5. Cruz-Jentoft AJ, Bahat G, Bauer J et al. Sarcopenia: revised European consensus on definition and diagnosis. Age Ageing 2019;48(1):16-31.

6. Fielding RA, Vellas B, Evans WJ, et al. Sarcopenia: an undiagnosed condition in older adults. Current consensus definition: prevalence, etiology, and consequences. International working group on sarcopenia. J Am Med Dir Assoc 2011;12(4):249-56.

7. Chen L-K, Liu L-K, Woo J, et al. Sarcopenia in Asia: consensus report of the Asian Working Group for Sarcopenia. J Am Med Dir Assoc 2014;15(2):95-101.

8. American Society of Hand Therapists (ASHT). Clinical Assessment recommendations -3rd edition, P.1-20. Consultable en ligne : http://ahint.epubxp.com/i/582310-3rdedition-2015-17.

9. Friedman PJ, Richmond DE, Baskett JJ. A prospective trial of serial gait speed as a measure of rehabilitation in the elderly. Age Ageing 1988;17(4) : 227-235.

10. Podsiadlo D, Richardson S. The timed up and go: A test of basic functional mobility for frail elderly persons. J Am Geriatr Soc 1991;39: 142-148.

11. Soubeyran P, Bellera C, Goyard J, et al. Screening for vulnerability in older cancer patients: the ONCODAGE Prospective Multicenter Cohort Study. PloS One 2014;9 (12) : e115060.

12. Oken MM, Creech RH, Tormey DC, et al. Toxicity and response criteria of the Eastern Cooperative Oncology Group. Am J Clin Oncol 198;25 (6): 649-655.

13. Katz S, Ford AB, Moskowitz RW, et al. Studies of illness in the aged: the index of ADL, a standardized measure of biological and psychological function. JAMA 1963;185: 914-919.

14. Lawton MP, Brody EM. Assessment of older people: self-maintaining and instrumental activities of daily living. Gerontologist 1969;9: 179-186.

15. Vellas BJ, Sharon J, Wayne MS et al. One-Leg Balance is an important predictor of injurious falls in older persons. J Am Geriatr Soc 1997;45 (6):735-738.

16. Guigoz Y, Lauque S, Vellas BJ. Identifying the elderly at risk for malnutrition. The Mini Nutritional Assessment. Clin Geriatr Med 2002;18(4):737-757.

17. HAS quick reference guide 2007. Nutritional support strategy for protein-energy malnutrition in the elderly. https://www.has-sante.fr/upload/docs/application/pdf/ malnutrition_elderly_quick_ref_guide.pdf Accessed August 2019

18. Folstein MF, Folstein SE, McHugh PR. "Mini-mental state". A practical method for grading the cognitive state of patients for the clinician. J Psychiatr Res 1975;12: 189 198.

19. Reijnierse EM, Trappenburg MC, Leter MJ et al. The impact of different diagnostic criteria on the prevalence of sarcopenia in healthy elderly participants and geriatric outpatients. Gerontology 2015;61:491- 496.

20. Moreira VG, Perez M, Lourenço RA. Prevalence of sarcopenia and its associated factors: the impact of muscle mass, gait speed, and handgrip strength reference values on reported frequencies. Clinics, 2019;DOI:10.6061/clinics/2019/e477.

21. Cruz-Jentoft A, Landi F, Schneider SM et al. Prevalence of and interventions for sarcopenia in ageing adults : a systematic review. Report of the International Sarcopenia Initiative (EWGSOP and IWGS). Age and Ageing 2014;43: 748-759.

22. Shimokata N, Shimada H, Satake $\mathrm{S}$ et al. Epidemiology of sarcopenia. Geriatr Gerontol Int 2018;18 (Suppl.1) : 13-22.

23. Walston J, Hadley EC, Ferrucci L, et al . Research Agenda for Frailty in Older Adults : Toward a Better Understanding of Physiology and Etiology: Summary from the American Geriatrics Society/National Institute on Aging Research Conference on Frailty in Older Adults. J Am Geriatr Soc 2006;54 : 991-1001.

24. Fried LP, Tangen CM, Walston $\mathrm{J}$ et al. Frailty in older adults : evidence for a phenotype. J Gerontol A Biol Sco Med Sci 2001;56 : M146-M156.

25. Winters-Stone KM, Moe E, Graff JN et al. Falls and frailty in prostate cancer survivors: current, past, and never users of androgen deprivation therapy. J Am Geriatr Soc 2017;65 (7): 1414-1419.

26. Wu FJ, Sheu SY, Lin HC, Chung SD. Increased fall risk in patients receiving androgen deprivation therapy for prostate cancer. Urology 2016;95: 145-150.

27. Alibhai SMH, Breunis H, Timilshina N, et al. Impact of androgen-deprivation therapy on physical function and quality of life in men with nonmetastatic prostate cancer. J Clin Oncol 2010;28:5038-5045.

28. Smith MR, Saad F, Egerdie B et al. Sarcopenia during androgen deprivation therapy for prostate cancer. J Clin Oncol 2012;30: 3271-3276.

29. Dawson JK, Dorff TB, Schroeder ET et al. Impact of resistance training on body composition and metabolic syndrome variables during androgen deprivation therapy for prostate cancer: a pilot randomized controlled trial. BMC Cancer 2018;18:368 doi 10.1186/s12885-018-4306-9

30. Lester-Coll NH, Goldhaber SZ, Sher DJ, D'Amico AV. Death from high-risk prostate cancer versus cardiovascular mortality with hormonal therapy: a decision analysis. Cancer 2013;119(10):1808-1815. 